Journal of Universal Language 8

March 2007, 51-89

\title{
Phonological Readjustment and Multimodular Interaction: Evidence from Kirundi Language Games*
}

\author{
Jeanine Ntihirageza \\ Northeastern Illinois University
}

\begin{abstract}
This paper investigates language games (also called ludlings [Laycock 1969, 1972, Bagemihl 1988a, 1995]) as linguistic tools used to unveil and understand phonological phenomena such as tone, vowel length and voice dissimilation. Although this study is comparative in nature, the focus is on novel data produced by Kirundi speakers. Three types of affixation language game data are
\end{abstract}

\footnotetext{
* This paper is an excerpt from my dissertation, Quantity Sensitivity in Bantu Languages, presented at the University of Chicago in 2001. I am grateful to James D. McCawley and John Goldsmith for their extensive comments on previous versions. An earlier version of this paper was presented the Annual Conference on African Linguistics 2006. For comments at this conference, I am also grateful to Larry Hyman and Sharon Rose. Additionally, colleagues at Northeastern Illinois University, namely Audrey Reynolds, Teddy Bofman and William Stone provided me with valuable feedback. Their comments, questions, and suggestions were particularly important for the development of this work.
} 
analyzed. The goal of this investigation is twofold. First I show that the only length and tone that matter are the ones that come floating with the affixed segmental material. Second, this paper discusses the issue of source language, i.e., where in the phonology of the language the game rules apply. Following Bagemihl's modular model $(1988,1995)$, couched in lexical phonology, I demonstrate that the source language of the language games belongs to different modules depending on the nature of the inserted material. I also show that one language game can pertain to different modules depending on its characteristics. Thus while the voice dissimilation rule is a level 2 morphological rule in Kirundi, the language game data indicate that this rule applies in both the lexical and post-lexical phonology as pointed out in (Goldsmith \& Sabimana 1989, Goldsmith 1992). All in all, this study examines what insights into the regular phonology of languages can be obtained through an analysis of the language game data.

Keywords: language games, Kirundi, vowel length, Bantu, tone, voice dissimilation

\section{Introduction}

The ease with which language games are invented makes them an interesting window onto how speakers analyze and manipulate the structures of their own languages. This paper examines what insights into the regular phonology of human languages can be obtained through an analysis of language game data. In this paper, the focus is on vowel length and tone behavior as well as the voice dissimilation rule in Kirundi language games. In other words, I show that these language games, like any other language game, constitute external evidence for the general phonological processes existing in the native speaker's grammar.

Although this study is comparative in nature, its focus is on novel data collected from Kirundi speakers. The most common type of language games in Burundi involves affixation. To the best of my 
knowledge, there are no studies that have looked at affixation in Bantu language games in relation to the behavior of vowel length or tone. The difference between the selected Kirundi based language games lies in the nature of the material inserted in the 'source language' and the nature of the output. These language games show that the mechanisms for deriving language game words do not exhibit patterns that are unusual in the Kirundi system. Moreover, language game rules respect the phonotactic constraints of the regular language. Secondly, it examines what insights into regular phonology of the language can be obtained through an analysis of the language game data. It shows that while language game data can help establish the status of vowel length and tone, an issue arises concerning the source language of the language game. All the data collected for the purpose of this paper are presented. They are organized according to the infixed material. For the sake of comparison other language games from other world languages, African and non African, are presented where appropriate. As it will be shown, this comparison makes it possible to highlight the universality of language games as a linguist tool.

A number of studies have used language games and other speech disguises for a wide range of purposes. Some language games have been analyzed in order to understand syllables and units that compose syllables (Cowan \& Leavitt 1990). These authors (1990: 58) claim, "Whereas linguists have not been able to agree on the definition of the syllable, there has been a fairly high level of agreement among disparate sources of performance data on syllables". The study of language games serves three main functions, namely, as a sociolinguistic tool, as evidence of linguistic structures, and as linguistic systems themselves. Many studies have provided definitions of language games, mostly focusing on their sociolinguistic aspect. A few of them, however, starting from Laycock (1972) and then Bagemihl (1988a, 1988b) have attempted to define language games from a formal perspective. 
Language games are referred to as 'play languages' or Ludlings, a term coined by Laycock (1972) from Latin ludus 'game' and lingua 'language'. He defines a ludling as "the result of a transformation or series of transformations acting regularly on an ordinary language text, with the intent of altering the form but not the content of the original message, for purposes of concealment or comic effect (Laycock 1972: 61). For the sake of the present paper, I adopt Bagemihl's formal definition (1995: 699). According to Bagemihl (1995: 699), "a ludling is defined as a language which meets the following criteria: (1) its morphological system is limited to one or more operations drawn from the following: (a) infixing/affixing, (b) templatic, (c) reversal, or (d) replacement; (2) its affixes (whether fully specified or defined only in prosodic or melodic terms) are limited to one or at most a handful of lexical items; and (3) its morphology is semantically empty." Bagemihl's definition is obviously incomplete since it does not include the fact that the input to the language game is an already existing linguistic system. Although Kirundi language games are structurally different, the linguistic similarities revealed in the structures of language game forms carry information regarding prosodic features, namely vowel length and tone in Kirundi.

The analysis of Kirundi language games is an attempt to reveal their importance in providing information about the internalized grammars of native speakers, the canonical syllable of the SOURCE LANGUAGE and the psychological reality of the phonological rules and constraints operating in the language. As Bagemihl (1995: 697) points out, "With the insights into phonological representation and non concatenative operations offered by autosegmental and prosodic models, language game operations were revealed to be systematic, principle-governed, and formally related to well known phenomena in ordinary language such as reduplication, in spite of their appearances to the contrary". In other words, in terms of their formal structure, language games were shown to differ not so much 
qualitatively from ordinary language, but rather quantitatively in the degree to which ordinary language operations were modified or extended in the derivation of language game forms. One ultimate question that Bagemihl brings up and which is relevant to this paper is "What do these systems tell us about the nonlinear representations, prosodic operations, etc. of their source languages?" An answer to this question will help shed some light on phonological phenomena across languages.

\section{Studies in Bantu Language Games}

Most of the Bantu language games analyzed so far in the literature involve reversal of segmental material. This is the case of two important studies, Hombert (1986) who studied Bakwiri spoken in Cameroon and Coupez (1969) who looked at Kishingelo-Sanga spoken in Zaire. Hombert (1986) contends that the original position of length remains unaffected in African language games involving permutation. This suggests that length, like tone, is a suprasegmental feature. Let us look at the vowel treatment in data (1) below, taken from Hombert's study:

\section{(1) Bakwiri word game}
a. lùùnga
$\rightarrow \quad$ Đgàalú
'stomach'
b. zéeyá
$\rightarrow$ yáazé
'burn'
c. ézèe
$\rightarrow \quad$ zéPèe
'it is not'

In this language game only the segmental material moves; neither the vowel length nor the tone is transposed with it.

Other studies in which Bantu language games have been analyzed focusing on vowel length and tone behavior include the secret language called Kishingelo, played by speakers of the Bantu 
language Sanga (Coupez 1969). It is spoken in the Democratic Republic of Congo (formerly known as Zaire). Coupez (1969) has demonstrated the independence of the phonemic level from the gross prosodic shape of the syllable. As shown by the examples in (2), (3), and (4), the disguise consists in interchanging the final two syllables of the word. However, the weight of the syllable remains unaltered. Thus, the Light-Heavy-Light profile of Sanga múkwèètù is preserved in Kishingelo mútùùkwè.

(2) a. Sanga óbé múkwèètù twáàyáá kú múkólá!

b. Kishingelo béó mútùùkwè yáàtwáá!

'You, my companion, come with me to the river!' (Coupez 1969: 33)

(3) a. báákólwèé bààdyáá mátábá àánkàámbò.

b. báálwékòó dyààbáá mábátá àámbòónkà.

'The monkeys eat my grandfather's corn.' (1969: 33)

(4) a. báànábákàjì bàà mú kóóngò bàátèmwáà kúdímá.

b. báàmábájìkà bàà mú ngóókò bàámwàtéè kúmádí.

'Congolese women like to cultivate the land.' (1969: 33)

It can be observed from examples (2), (3), and (4) that the length and tone structure of Sanga is preserved in Kishingelo, although the sound structuremay have been violated. For instance, the lengthening of a vowel after a consonant + glide cluster does not seem to hold in the output of the Kishingelo rule. Thus, the change of báákólwèe to báálwékòó produces such a violation. It is quite clear that Kishingelo rule applies to the phonetic form after the lengthening rule has applied. The Kishingelo rule poses a problem to those theories that suggest that phonetic forms are a result of low-level phenomena and no phonological rules refer to those forms (those for whom phonetic forms are useless for phonological rules). 
The constancy of weight is easy to express under the moraic representation. Interchanging the phonemic content of the last two syllables while preserving the syllabic and moraic structure yields the correct result. It can, therefore, be concluded that in the Bakwiri language game as well as in Kishingelo, vowel length and tone are best analyzed as a property of the entire word rather a property of the syllable.

This investigation has two main interrelated objectives. (1) To identify and describe phonologically what are construed as language games in Kirundi; (2) To use language games as a means for examining phonological structures. Overall, this analysis will provide insights into the analysis of phonological issues such as tone, vowel length, and voice dissimilation. Three sets of affixation data are presented in the following section.

\section{Kirundi Language Games}

\subsection{Subjects}

The language game data are original. The games are widely played among children throughout Burundi. The data on which this section is based are gathered from Kirundi native speakers. Although the subjects do not use these language games on a regular basis, they are very conversant in Kirundi word games. The data were recorded from three principal subjects who come from different regions in Burundi. These subjects regularly used the language either at home with their brothers and sisters or with their fellow shepherds or at school with their schoolmates. The ideal situation for these languages to be spoken was when these children were in the presence of adults. They would then use Incanganyo (name of Kirundi language game) so that the grown-ups could not understand the hidden message. Although the speech of Burundian 
youth is very productive in terms of speech disguises, this study is only based on infixation language game data.

\subsection{Data}

The language games presented in this section all involve the first operation mentioned above in Bagemihl's definition of a language game, i.e., infixation. They all exhibit an impoverished morphological system superimposed on the ordinary or non-ludling language. Moreover, unlike regular affixes, the language game infixes are semantically empty. As Bagemihl (1988b: 37-38) points out, the added elements "signal that an exceptional register is being used to classify the speaker or hearer as belonging to a particular category of individual.... In particular they cannot be considered to modify or combine with the meaning of the words they are attached to or to carry information about other words in the sentence as do other meaningful affixes." The affixes are dummy and are selected only for the 'secret language' purpose.

The games discussed in this paper differ in the size and nature of the infixed material. One type, the / $\mathrm{mnV} /$ and $/{ }^{\prime \mu} \mathrm{sV} /$ games, involves the insertion of partly prespecified elements, while in the other type the melodic content of the inserted affix is thoroughly prespecified. ${ }^{1}$ As Bagemihl (1995: 711) points out, the term 'infix' is something of a misnomer in this case. The ludling treats each syllable of the non-ludling word as an individual (prosodic) word to which the affix is added, giving the impression of infixation.

It is important to note that these languages are in no way influenced by the Kirundi orthographic system since even illiterate children play them. The games are named Incanganyo 'mixers' from the verb gucanganya 'to mix' which means 'to mix/to confuse'. One

1 Kirundi does not have any such a sequence $/ \mathrm{mn} /$ ) in its phonemic inventory. Also, the symbol "' refers to the high tone in this language. 
may think that the name has a structural meaning to it since the examples provided below all involve mixing elements with others. However, the same name is given to language games involving reversal of the root material.

\subsubsection{Game I: /'mnV/ Affixation}

The /'mnV/ language game counts the whole phonological word as its domain of infixation. As it is shown in the data, the tone and consonant cluster sequence are inserted in the penultimate position of the non-ludling. The penultimate vowel is copied to the right of the inserted consonant cluster $/ \mathrm{mn} /$ so as to form an independent syllable. The floating High tone is then assigned on the penultimate mora or syllable of the non-ludling phonological word. It is only inserted in penultimate position of a phonological word. The purpose of using a cluster that does not exist in the language is to create something that is very foreign to the non-intended listener. The deformation created in the language game becomes very different from regular Kirundi. What distinguishes this language game from the others considered below is the extent to which the melody is aligned to the prosodic structure.

An inspection of the data that use /' $m n$ / infixation reveals that the structure preservation is violated in the input since Kirundi does not have clusters such as $/ \mathrm{mn} /$ or any other consonant clusters, except consonant and glides or prenasalized consonants, as onset in its syllables. The idea that $/ \mathrm{m} /$ could be part of the coda and $/ \mathrm{n} /$ part of the onset distributed in two different syllables is refuted by the fact that the Kirundi canonical syllable template is basically $(\mathrm{C}) \mathrm{V}(\mathrm{V})$. This non-structure-preserving operation is also discussed by Bagemihl (1988a: 412). His study suggests that this language game operates at the postlexical level since the lexical level is structure preserving. The data on Kirundi language games are presented as follows. The first line corresponds to the regular Kirundi forms. The 
60 Phonological Readjustment Kirundi Language Games

second line represents the game forms, whereas the third is the corresponding gloss.

(5) Kirundi: Ntá masáka akúra atéeze. -'mnV game: Ntá masámnaka akúmnura atémneze. 'No sorghum grows without being ripe.'

(6) Kirundi: NtawutáAnguranwa n’umwáaka. -'mnV game: Ntawutangurámnanwa numwámnaka. 'Nobody competes with the year.'

(7) Kirundi: Akamarampáka n'amasílnde araaye. -'mnV game: Akamarampámnaka namasímninde arámnaye. 'the most challenging (thing) is a field that's late to be cultivated.'

(8) Kirundi: umwúungere w'índa ntacúura

-'mnV game: umwungémnere wímninda ntacúmnura Kirundi: amahóro imírsi yóóse.

-'mnV game: amahómnoro imímnisi yómnose. 'A shepherd of the stomach does not always bring peace home.'

(9) Kirundi: Ú'údafíse úúmuvuUmba ntaróonka -'mnV game: Udafímnise umuvúmnumba ntarómnonka Kirundi: úlúmuvuumvya.

-'mnV game: umuvúmnumvya

'The one who doesn't have anybody to ask for beer does not get anybody to invite him/her for beer.'

(10) Kirundi: Imbúragihána yabúze giháamba. -'mnV game:Imburagihámnana yabúmnuze gihámnamba. 'The one who doesn't have anybody to scold him/her does 
not get anybody to bury him/her.'

\subsubsection{GAME II: $/^{\prime \mu} \mathrm{sV} /$ affixation $^{2}$}

As pointed out by Hayes (1995: 4-20), vowel lengthening is a common correlate of metrical prominence cross linguistically. This is especially true in Bantu languages, many of which are characterized by penultimate vowel lengthening. The metrical prominence falls on the penult of a phonological word. This process is reflected in the $/{ }^{\mu} \mathrm{s} \mathrm{S} /$ language game spoken by Kirundi speakers. The affix $/{ }^{\prime \mu} \mathrm{sV} /$ is inserted after each syllable of the stem. The preceding vowel is copied. This language game requires the penultimate position of the phonological word in the game to be heavy. This game simultaneously counts the syllable and the whole phonological word. On one hand, the $/ \mathrm{sV} /$ is inserted after every syllable, and it is the vowel of each syllable that is copied. On the other hand, the floating vowel length and tone associated with the dummy affix are assigned to the final mora of the non-ludling phonological word, thus producing a long penultimate syllable in the ludling. The autosegments are to be associated with the final mora of a phonological word.

(11) Kirundi: Ntá masáka akúra atéeze. $-{ }^{\prime \mu} \mathrm{sV}$ : Ntasamasasasakáasa asakúsuráasa asatesezéese. 'No sorghum grows without being ripe.'

(12) Kirundi: Ntáwuutáanguranwa n'úumwáaka. $-{ }^{\prime \mu} \mathrm{sV}$ : Ntasawusutasangusurasanwáasa n'usumwasakáasa. 'Nobody competes with the year.'

2 ]: indicates pause inside an utterance vv (long vowel): indicates a long vowel underlyingly and at the surface $\mathrm{vV}$ (long vowel): indicates an underlying long vowel which shortens at the surface level. 
62 Phonological Readjustment Kirundi Language Games

(13) Kirundi:

Akamarampáka n'amasíinde araaye. $-{ }^{\prime \mu} \mathrm{SV}$ :

Asakasamasarasampasakáasa n'asamasasisindéese asarasayéese. 'the most challenging (thing) is a field that's late to be cultivated.'

(14) Kirundi: Umwúúngere w'índa ntacúúra

-' $\mu \mathrm{sV}$ : Usumwusungeseréese w'isindáasa ntasacusuráasa Kirundi: amahóro imísi yóóse.

-' $\mu \mathrm{sV}$ : asamasahosoróoso isimisíisi yososeese.

'A shepherd of the stomach does not always bring peace home.'

(15) Kirundi: Ú!údafise ú!úmuvuumba

- ${ }^{\prime \mu} \mathrm{sV}$ : Usudasafisiséese usumusuvusumbáasa

Kirundi: ntáróonka ú!úmuvuumvya.

-' ${ }^{\prime \mu} \mathrm{V}$ : ntasarosonkáasa usumusuvusumvyáasa.

'The one who doesn't have anybody to ask for beer does not get anybody to invite him/her for beer.'

(16) Kirundi: Imbúragihána yabúze

$-{ }^{\prime \mu} \mathrm{sV}$ : Isimbusurasagisihasanáasa yasabusuzéese

Kirundi: giháamba.

$-{ }^{\prime \prime} \mathrm{sV}$ : gisihasambáasa.

'The one who doesn't have anybody to scold him/her does not get anybody to bury him/her.'

The examples in (11) through (16) illustrate that penultimate lengthening and High tone assignment apply at the penultimate position of a phonological word, also marked by an important pause at the end of the word. As the data suggest, the extra mora and the High tone inserted by the language game are intimately related and 
are assigned at the same position.

\subsubsection{GAME III: /'ka/ infixation}

The affixation of /'ka/ applies in polysyllabic phonological words. The language game affix -'ka is inserted after every syllable in a polysyllabic word, with the exception of the final syllable. This language game counts the syllable as a prosodic word, but counts the final syllable as extraprosodic. It is also possible to interpret this rule as the insertion of $/$ " $k a /$ before every syllable except the first. This rule also assigns a High tone to every syllable preceding the $k a$ syllable. In other words, /' $k a /$ is not inserted at word edges. There is no strong evidence in favor of the former or the latter position. However, the game rule delivers best when it is articulated in terms of right hand affixation, i.e. suffixation, since the high tone is always assigned to the syllable preceding the affix. In any case either the final syllable or the initial is extraprosodic after one has built a prosodic structure for the language game forms.

The aesthetic feature of this language game is its rhythmic melody, which is achieved through insertion of /' $\mathrm{ka} /$, the alternating high-low pattern, and the shortening of long vowels. The fascinating aspects of this linguistic creativity are shown first in its spontaneity of creating language game versions as well as in the speed with which these speakers systematically modify lengthy utterances into language game forms.

(17) Kirundi: Ingo háno] nkubwíire.

-'ka game: íkangó kahákano nkúkabwíkare.

'Come here I tell you.'

The imperative form ingo 'come' forms a phonological word with the following word. Thus the serial verbs ingo utóore are realized as ingw'utóore 'come get' in one word. This fact accounts 
for the placement of the $/ \mathrm{ka} /$ immediately after ingo, whereas if it formed an independent word by itself $/ \mathrm{ka} /$ would not be inserted after the syllable -ngo since it would be in the final position.

(18) Kirundi: Hárabaay’abáana babiri] báavuuka

-'ka game: Hákarákabákaye ákabákana bákabíkari

Kirundi: k'umugabo umwé yari

-'ka game: bákavúkaka kúkamúkagákab'úkamwe yákari

Kirundi: umuhíizi.

-'ka game: úkamúgahíkazi

'There were two children who were born from one man who was a hunter.'

(19) Kirundi: Umúús'umwé sewáabo] ageenda

-'ka game: úkamúkasúkamwe sékawákabo ákagékanda

Kirundi: guhíiga

-'ka game: kúgahíkaga.

'One day their father went to hunt.'

Forms like úkamúkasúkamwe from Umúús'umwé show that the game rule applies at the phrase level since the input word umuusi is lexically long. However, a phrasal shortening rule applies and shortens the long vowel of umúúsi once it is adjoined to umwé, which is a phrase level rule. In this case, vowel shortening is therefore not a result of the application of the game rule but of the phrasal shortening rule.

(20) Kirundi: imvúra iragwa] sewáabo] -'ka game: íkamvúkara íkarákagwa sékawákabo Kirundi: atariho.

-'ka game: ákatákaríkaho.

'The rain fell while their father was not there.' 
Example (20) constitutes evidence for the realization (or lack) of the voice dissimilation rule, very productive in Kirundi. This rule voices an obstruent in a morpheme that immediately precedes a stem beginning with a voiceless obstruent. The game form áka-táka-rikaho derived from a-ta-ri-ho (literally: s/he not be there) shows that the voice dissimilation rule strictly applies at the boundary between a prefix and a stem (ka-rí), not between two prefixes (ka-tá) even if the segmental requirements for the rule application are met. If the voice dissimilation rule were to apply at any morpheme boundary, the game form from atariho would be ágatákaríkaho.

(21) Kirundi: Yarimwo] imiravyo.

-'ka game: Yákaríkamwo íkamíkarákavyo

'There were thunders with it.'

(22) Kirundi: Abo báana]

-'ka game: ákabókabákana bákarákagíkarúkabwókaba

Kirundi: baragir'ubwóoba] kuko báari bato.

-'ka game: kúkako bákari bákakíkari bágato.

'Those children had fear because they were young.'

(23) Kirundi: Sewáabo] iyo yar'áari] mw'ishaamba]. -'ka game: Sékawákabo íkayo yákarákari mwígashákamba. 'Their father was in the forest.'

(24) Kirundi: Atáangura kwiyumviira]

-'ka game: ágatákangúkara kwíkayúkamvíkara

Kirundi: abo báana.

-'ka game: ákabókabákana.

'He started thinking about those children.'

(25) Kirundi: Umwáanumwé yari akuze], -'ka game: úkamwákana úkamwe yákari ágakúkaze, 
'One child was big.'

(26) Kirundi: abóonye] biméze gutyo], -'ka game: ákabókanye bíkamékaze kúgatyo, 'When he saw what the situation was like.'

(27) Kirundi: afata umwaango] arawuugara], -'ka game: ágafákata úkamwákango ákarákawúkagákara, 'He closed the door.'

(28) Kirundi: aca acaana] n'umucáanwa. -'ka game: ágaca ágacákana núkamúgacákanwa 'Then he lit the fire.'

(29) Kirundi: kugira mutóoyi wíiwé] -'ka game: kúgakíkara múgatókayi wíkawe Kirundi: ashobore kwoota. -'ka game: ágashókabókare kwókata. 'So that his young sister/brother can warm up.'

Examples (24), (27), (28) and (29) illustrate the realization of the voice dissimilation rule. As stated earlier in the previous section, this rule voices an obstruent in a prefix that is adjacent to a noun, verb, or adjective stem beginning with a voiceless obstruent. The language game infixed syllable /' $\mathrm{ka} /$ is realized as $[\mathrm{ga}]$ when the structural conditions for the application of the rule are satisfied. Two issues arise here. The first is the nature of the input to the language game. The second issue concerns module interaction. A morphological rule applies to the output of phonology, which constitutes a problem for Lexical Phonology. 


\section{Phonological analysis}

\subsection{Quantity Analysis}

This section is concerned with the status of vowel length in the language game data provided above. In Kirundi language games described above, long vowels only appear in the penultimate position. While long vowels shorten in most positions, length survives in the penultimate position of words and phrases. Thus, the $/{ }^{\mu} \mathrm{s} \mathrm{V} /$ word game assigns length to the final syllable of the original phonological words. The resulting length appears in the penultimate position of the game forms as shown in (30).

(30) Kirundi: Ntá masáka akúra atéeze. -'H $\mathrm{sV}$ : Ntasamasakáasa asakúsuráasa asatesezéese. 'No sorghum grows without being ripe.'

It is important to note that the word for 'no', ntá, forms a phonological word with the following word, masáka 'sorghum'. If it were an independent word, "-sa" would not be inserted after ' $n t a$ ' because this dummy infix is not inserted at the end of a word.

The $/{ }^{\prime \mu} \mathrm{sV} /$ game requires shortening of all the input long vowels. In other words, whether underlying or derived, long vowels shorten in the game words. Thus each Kirundi word in the following example (31) has a derived long vowel in it. However, none of the long vowels surface in the game words. We instead observe vowel length where it does not exist in the original forms. All surface long vowels in the language game are a result of the game affix insertion.

(31) Kirundi: Ú'údafise ú'úmuvuumba $-{ }^{\prime \mu} \mathrm{SV}$ : Usudasafisiséese usumusuvusumbáasa Kirundi: ntáróonka ú'úmuvuumvya. $-{ }^{\prime \mu} \mathrm{sV}$ : ntasarosonkáasa usumusuvusumvyáasa. 
'The one who doesn't have anybody to ask for beer does not get anybody to invite him/her for beer.'

Conversely, some games, namely /'mnV/ and /'ka/, require shortening of all original long vowels in the derivation of the game forms for the sake of foot construction. The foot resulting from that derivation may only consist of light-light syllables. This is observed in the /'mnV/ game and the /'ka game/. Additional examples are provided in table 1 below.

Infixation games are not uncommon in the world's languages and oftentimes involve shortening of the input long vowel. For example, the Estonian -pi- Game (Lehiste 1985: 491-492) involves long vowel delinking. The game consists of an epenthesis of a syllable -pi- after the first vowel of an Estonian word. If that first vowel is long, it is shortened after -pi- insertion, and the /i/ of the inserted syllable is lengthened, becoming -pii-. Similarly, in Kirundi the underlying vowel length does not surface at all in the output of the language game.

Other cases of language game affixation have been investigated by Alidou (1997), mostly in Hausa. Just like Kirundi language games, these Hausa language games impose a prosodic structure on the source language (Alidou 1997: 33), namely the tone and length pattern as well as the syllable structure. The $/ \mathrm{bV} /$ game, referred to as the hábà?ábà, adds the suffix $/ \mathrm{bV} /$ after each $\mathrm{CV}$ of the word except the last. The $\mathrm{V}$ that is copied can be a monophthong or diphthong. The game involves (1) shortening of long monophthongal vowels including the last; (2) imposition of an alternating High-Low tone pattern with the assignment of the high tone to the syllable original Hausa word, while the suffix /bV/ carries a low tone. The assignment of tone pattern and the syllable structure of the game suggest a requirement for the formation of trochaic feet. While Alidou sees the affix as composed of solely segmental material, /bV/, treating the tonal component separately, I include the suprasegmental 
material in the affix package for Kirundi language games.

Another variety of suffixation, analyzed by Alidou (1997: 36), employs an insertion of $/ \mathrm{grV} /$. This game inserts the sequence $/ \mathrm{grV} /$ after each syllable. As with the $/ \mathrm{bV} /$ word game, the $/ \mathrm{grV} /$ game also requires shortening of long monophthongal vowels and the alternation of High-Low tone pattern where the original syllable carries a high tone and $/ \mathrm{grV} /$ affix has a low tone. This game, like the Kirundi /'mn/ word game, is significant because it shows that although the normal phonotactics of Hausa prohibit consonant clusters within a single syllable, Hausa native speakers can, for the purpose of speech disguise, use an unnatural syllable initial cluster /gr/ in deriving the language game forms.

The Hausa word game that is similar to the Kirundi $/{ }^{\prime \mu} \mathrm{sV} /$ game is referred to as the Pásàdásà word game. According to Alidou (1997: 42), it is played by Hausa teenagers in the Dogon Doutchi area for fun and is intended to mimic the sounds of the Fula language. Unlike the other types of suffixation games discussed above, this game inserts the suffix $/ \mathrm{sV} /$ after the coda of each syllable including the last and shortens all original monophthongal long vowels including word ending long vowels.

In contrast, the Kirundi /sV/ game lengthens the final syllable mora, thus creating a penultimate heavy syllable in the phonological word (rather than the prosodic word) of the language game. Alidou says that like the $/ \mathrm{bV} /$ and $/ \mathrm{grV} /$ games, the $/ \mathrm{sV} /$ game also imposes an alternating high-low tone pattern on the derived game forms: the original syllable carries a high tone while $/ \mathrm{sV} /$ has the low tone.

All three Hausa games, the $/ \mathrm{bV} /, / \mathrm{grV} /$ and the $/ \mathrm{sV} /$ games, show structural similarities regarding their treatment of vowel length and tone structure. However, although Kirundi language games show similarities in the tone and vowel length assignment, they differ in where the tone and the vowel length are assigned. Thus the /'ka/ game involves vowel shortening of all long vowels and the assignment of a High tone on every syllable that precedes $/ \mathrm{ka} /$. The 
/'mn/ game requires a vowel shortening of all long vowels, a copy of the preceding vowel, and the assignment of a High tone on the syllable that precedes $/ \mathrm{mnV} /$. Finally the $/{ }^{\prime \mu} \mathrm{sV} /$ game calls for vowel length contrast neutralization everywhere. A floating mora (part of the affix package) is associated with the regular word final vowel, thus making it long in the penultimate position of the game form. The difference between the applications of the game rules in these three games is highlighted in Table1. The phonological rules of these language games completely neutralize the underlying vowel length.

Table 1. Minimal Pairs/Triplets

\begin{tabular}{|c|c|c|c|c|c|}
\hline & Gloss & Kirundi & $I^{\prime}-\mathbf{m n V}-/$ & $I^{6} \mu \mathrm{s} V /$ & -'ka- \\
\hline $1 \mathrm{a}$ & chicken & $i^{\mathrm{n}}$ kóko & $i^{\mathrm{p}}$ kómnoko & isi ${ }^{\mathrm{p}}$ kosokóoso & íka ${ }^{\mathrm{n}}$ kókako \\
\hline $1 \mathrm{~b}$ & small basket & $i^{\mathrm{g}}$ kóoko & $\mathrm{i}^{\mathrm{n}}$ kómnoko & isi ${ }^{{ }^{n}}$ kosokóoso & íka ${ }^{\mathfrak{1} k o ́ k a k o}$ \\
\hline & & & & & \\
\hline $2 a$ & seeds & $\mathrm{i}^{\mathrm{n}} \mathbf{z u ́ z i}$ & $\mathrm{i}^{\mathrm{n}}$ zúmnuzi & isi $^{\mathrm{n}}$ zusuzíisi & íka ${ }^{\mathrm{n}}$ zúkazi \\
\hline $2 b$ & rivers & $\mathrm{i}^{\mathrm{n}}$ zúuzi & $i^{\mathrm{n}}$ zúmnuzi & isi ${ }^{\mathrm{n}}$ zusuzíisi & íka zúkazi \\
\hline $3 a$ & oarden eoos & ${ }^{n}$ tore & 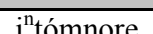 & issin tosoréese & f́ka tókare \\
\hline $3 \mathrm{~b}$ & small dough & $i^{n}$ tóre & $\mathrm{i}^{\mathrm{n}}$ tómnore & isi ${ }^{\mathrm{n}}$ tosoréese & Íka tókare \\
\hline $3 \mathrm{c}$ & $\begin{array}{c}\text { brave } \\
\text { person }\end{array}$ & $i^{n}$ tóore & $i^{n}$ tómnore & isi ${ }^{n}$ tosoréese & íka ${ }^{\mathrm{n}}$ tókare \\
\hline & & & & & \\
\hline $4 a$ & $\begin{array}{c}\text { To be about } \\
\text { to break }\end{array}$ & kurara & kurámnara & kusurasaráasa & kúkarákara \\
\hline $4 b$ & \begin{tabular}{|c|}
$\begin{array}{c}\text { to spend the } \\
\text { night }\end{array}$ \\
\end{tabular} & kuráara & kurámnara & kusurasaráasa & kúkarákara \\
\hline $5 \mathrm{a}$ & to ask & gusaba & gusámnaba & gususasabáasa & kúgasákaba \\
\hline $5 b$ & to shatter & gusaaba & gusámnaba & gususasabáasa & kúgasákaba \\
\hline $6 \mathrm{a}$ & to hide & guhífa & guhímnifa & gusuhísifáasa & 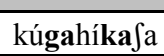 \\
\hline $6 b$ & $\begin{array}{c}\text { to finish } \\
\text { (cook) }\end{array}$ & guhíifa & guhímniða & gusuhísifáasa & 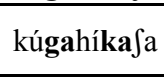 \\
\hline $7 \mathrm{a}$ & to work & gukóra & gukómnora & gusukosoráasa & kúgakókara \\
\hline $7 \mathrm{~b}$ & to peel & gukoora & gukómnora & gusukosoráasa & kúgakókara \\
\hline
\end{tabular}




\begin{tabular}{|c|c|c|c|c|c|}
\hline & Gloss & Kirundi & $I^{\prime}-\mathbf{m n V}-/$ & $/{ }^{6} \mu \mathrm{sV} /$ & -'ka- \\
\hline $8 \mathrm{a}$ & to cut & gukéka & gukémneka & gusukesekáasa & kúgakékaka \\
\hline $8 \mathrm{~b}$ & to doubt & gukéeka & gukémneka & gusukesekáasa & kúgakékaka \\
\hline & & & & & \\
\hline $9 \mathrm{a}$ & $\begin{array}{l}\text { to be hot } \\
\text { (food) }\end{array}$ & gukéra & gukémnera & gusukeseráasa & kúgakékara \\
\hline $9 b$ & $\begin{array}{c}\text { To be } \\
\text { welcoming }\end{array}$ & gukéera & gukémnera & gusukeseráasa & kúgakékara \\
\hline 10a & to curse & gusiba & gusimniba & gususisibáasa & kúgasíkaba \\
\hline $10 \mathrm{~b}$ & \begin{tabular}{|l|} 
to miss (an \\
appointment
\end{tabular} & gusiiba & gusimniba & gususisibáasa & kúgasíkaba \\
\hline & & & & & \\
\hline $11 \mathrm{a}$ & to grow & gukúra & gukúmnura & gusukusuráasa & kúgakúkara \\
\hline $11 \mathrm{~b}$ & to remove & gukúura & gukúmnura & gusukusuráasa & kúgakúkara \\
\hline & & & & & \\
\hline $12 \mathrm{a}$ & $\begin{array}{l}\text { To have } \\
\text { hardships }\end{array}$ & gukúba & gukúmnuba & gusukusubáasa & kúgakúkaba \\
\hline $12 \mathrm{~b}$ & to grind & gukuuba & gukúmnuba & gusukusubáasa & kúgakúkaba \\
\hline & & & & & \\
\hline $13 \mathrm{a}$ & \begin{tabular}{|c|} 
to miss (not \\
to find
\end{tabular} & kubúra & kubúmnura & gusubusuráasa & kúkabúkara \\
\hline $13 \mathrm{~b}$ & \begin{tabular}{|c|} 
sweep \\
\end{tabular} & kubuura & kubúmnura & kusubusuráasa & kúkabúkara \\
\hline $13 \mathrm{c}$ & $\begin{array}{c}\text { to announce } \\
\text { (death) }\end{array}$ & kubúura & kubúmnura & gusubusuráasa & kúkabúkara \\
\hline $14 \mathrm{a}$ & to open & gufuu ${ }^{\mathrm{n}}$ guura & gufu $^{\mathrm{n}}$ gúmnura & gusufusu $^{\mathrm{p}}$ gusuráasa & kúgafúka ${ }^{\mathrm{n}}$ gúkara \\
\hline $14 \mathrm{~b}$ & to eat & gufuu ${ }^{\mathrm{n}}$ gura & gufu ${ }^{\mathrm{p}}$ gúmnura & gusufusu ${ }^{\mathrm{g}}$ gusuráasa & kúgafúka ${ }^{\mathrm{y}}$ gúkara \\
\hline $15 \mathrm{a}$ & to drop & gukorora & gukorómnora & gusukosorosoráasa & kúgakókarókara \\
\hline $15 b$ & to cough & gukórora & gukorómnora & gusukosorosoráasa & kúgakókarókara \\
\hline $16 \mathrm{a}$ & like a cow & $\mathrm{y}_{\mathrm{k} i} \mathbf{u}^{\mathrm{n}} \mathrm{n} \mathrm{ka}$ & ${ }^{\mathrm{g}} \mathrm{kímni}^{\mathrm{I}} \mathrm{ka}$ & ${ }^{\mathrm{y}}$ kisi ${ }^{\mathrm{p}}$ káasa & ${ }^{{ }^{\mathrm{y}} \text { kíka }{ }^{\mathrm{n}} \mathrm{ka}}$ \\
\hline $16 b$ & no & eka & émneka & esekáasa & ékaka \\
\hline $16 \mathrm{c}$ & a small cow & agaka & akámnaka & asagasakáasa & ágakákaka \\
\hline $17 \mathrm{a}$ & in the forest & mw'i $a a^{m}{ }^{m} b a$ & 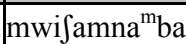 & 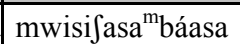 & mwígafáka ${ }^{\mathrm{m}}$ ba \\
\hline $17 \mathrm{~b}$ & $\begin{array}{c}\text { of }[\text { Class 12] } \\
\text { one man }\end{array}$ & \begin{tabular}{|c|} 
Ko \\
umugabo \\
umwe
\end{tabular} & $\begin{array}{l}\text { Kumugabú- } \\
\text { mnumwe }\end{array}$ & $\begin{array}{l}\text { Kusumusugasa- } \\
\text { busumwéese }\end{array}$ & $\begin{array}{l}\text { Kúkamúkagá- } \\
\text { kabúkamwe }\end{array}$ \\
\hline
\end{tabular}




\section{2. Tonal Analysis}

First, as is commonly assumed in the analysis of most Bantu languages, I proposed that low tones are completely underspecified underlyingly as in Pulleyblank (1986) and Clements \& Goldsmith (1984, Introduction). A late rule in the phonology will supply any toneless syllable with a default Low tone. In the /'mnV/ language game tone is deleted everywhere in the original forms. Then the affix tone is assigned on the mora preceding the /' $\mathrm{mnV} /$ sequence. Unlike the first example in the set, the second example shows that the tone is assigned to the mora preceding the /' $\mathrm{mnV} /$ segmental material irrespective of where the underlying High tone was. Similarly, in the $/{ }^{\prime \mu} \mathrm{sV} /$ game the High tone is deleted everywhere in the original phonological words but is reassigned before the final ${ }^{\mu} \mathrm{sV} /$ that is inserted, i.e, before mora assignment and the final melodic association of $/ \mathrm{s} /$. As the data show, just like vowel length, tone is not contrastive in the output since it is predictable.

Hombert (1986) has proposed that whether or not tone moves in a language game is a function of whether tone is represented suprasegmentally in that language. Thus, tone is predicted to behave uniformly across all ludlings in a given language. As the data show, language games in Kirundi support the issue of the suprasegmental status of the tone since the underlying tone deletes everywhere, leaving the segmental material behind.

\subsection{Prosodic Analysis}

In this section I examine how the Kirundi language games data can be analyzed within a prosodic formalism. As articulated in the introduction of this paper, this study touches upon the behavior of prosodic features such as tone and length. It provides insight into the native speakers' intuition concerning phonological constituents and suprasegmentals, as well as upon phonotactic constraints. 
The prosodic theory, as presented in McCarthy \& Prince (1986, 1990), fits best the analysis of Kirundi language game data because of its description. He contends that infixation games insert material into the $\mathrm{CV}$-skeleton with associated consonants while the root tier is left unchanged. He demonstrates that there are two types of infixation games. One type involves the insertion of partly specified elements, while in the other type the melodic content of the inserted affix is prespecified. The prosodic account also holds for the types of infixation games in which the prespecified string is either a vowel or a consonant. Let me now consider how the prosodic structure works in the Kirundi /'mnV/ language game.

(40) a. Kirundi /'mn/ infix

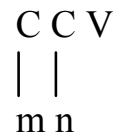

b. Underlying Form

CVCV

$1 \mid 1$

k o r a

$\mathrm{m} \mathrm{n}$

c. Infixation<smiles></smiles><smiles></smiles><smiles>C1=CC=C1</smiles>

k o

r a

d. Vocalic Association

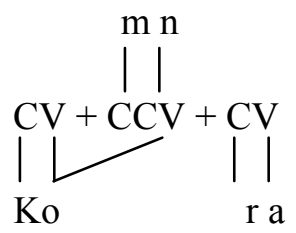

e. Surface Representation

kómnora 
74 Phonological Readjustment Kirundi Language Games

The prosodic theory (McCarthy \& Prince 1986, 1990) thus accounts for the highly rhythmic structure observed in Kirundi language game data.

One argument advanced in favor of the prosodic model of infixation and automatic association in language games is that the same analysis also applies to morphological processes occurring in regular languages. Bagemihl (1988a) maintains that the two types of linguistic systems differ only because language game forms do not add new meaning to the derived forms, whereas morphological derivations in normal languages do affect meaning. Furthermore, while the target of infixation in normal languages involves morphemes, infixation games generally target the syllable. In other words, game infixes are inserted at a specific location within and at the margin of the syllable. Thus, each syllable of the regular word is treated in the language game derivation as a virtual word to which the game infix is attached. In this sense, the inserted material should be treated as suffixes rather than infixes.

According to Bagemihl (1988a) an advantage of the prosodic account of infixation games is that the automatic association of the vocalic melody does not violate the constraint against crossing the association lines. This applies to the segmental material as well as the tonal material in Kirundi language games data. McCarthy and Prince $(1986,1990)$ also point out the relevance of the typological correlation between the shape of a game's infix and the location of its insertion. He argues that while games that insert CV (where $\mathrm{C}$ is prespecified) are common, it would be also logical to expect a type of language game that would prefix $\mathrm{pV}$ - (where $\mathrm{V}$ is unspecified). McCarthy shows that this type of infixation game does not exist because the derivation of their language game forms would violate the constraint against crossing association lines and this is prohibited within the prosodic model. This advantage is not strong in Kirundi. It would not be surprising to find a Kirundi language game of the type (C) $\mathrm{V}$ prefix since it already has a similar 
prefixation in noun formation. The augment in Kirundi is generally formed by copying the vowel of the noun class prefix as illustrated below (41).

(41)
a. u-muu-ntu 'person'
u-wuú-ndi 'the other (cl.1, cl.3)'
b. i-kii-ntu 'thing',
i-kií-ndi 'the other (cl. 7)
c. a-baa-ntu 'people'
a-baá-ndi 'the other (cl. 2)'
d. $u$-gu-twi 'ear'
a-ma-twi 'ears'

The examples in (41) illustrate a violation against the no crossing association lines constraint. Since Kirundi already has this infixation (more specifically, prefixation rule) in its system, it would be logical to expect a type of language game that would prefix an unspecified $\mathrm{V}$, where $\mathrm{V}$ would be filled by copying a vowel that already exists in the word. On the other hand, the account that prefixation of unspecified material does not exist in language games due to the ban on crossing association lines can be refuted by positing a representation of consonants and vowels on different tiers. This solves the issue of crossing association lines.

The account on the prosodic typology of language games by McCarthy \& Prince $(1986,1990)$ includes a large body of language games in several languages that use infixation (and transposition, which is not the concern of this discussion). He argues that these varieties of patterns provide strong support for a prosodic model of phonological representation. The main assumption in McCarthy's prosodic theory is that the target of infixation (and transposition) processes is a prosodic template composed of the units $\mathrm{C}$ and $\mathrm{V}$, and referred to as a CV skeleton. Other types of prosodic templates include syllables and various types of syllables. The prosodic template gains its melodic content by a process that copies the segmental content of the stem and then matches one-by-one the copied phoneme to the prosodic template.

Bagemihl (1995: 708) affirms that, "although many descriptive 
and theoretical accounts of ludlings are now available ... an adequate treatment of language games should capture the empirical typology within the confines of a parameterized theory". I will demonstrate that the three types of language games instantiate three possible levels of "source language" that are independently established in phonology.

A number of other authors have made passing statements about which level(s) of representations they consider to serve as input to the particular ludling they are examining (e.g., Yip 1994: 640; McCarthy \& Prince 1986: 229; Cowan, Braine, \& Leavitt 1985: 687; Churma 1985: 90). While there is no overall consensus on the location of ludlings, these authors seem to share the observation that ludling conversion may take place at some intermediate level or levels of representation within the phonology. Some authors also hypothesize that either quite shallow (surface) representations or fairly deep (lexical or underlying) representations may serve as input. The most comprehensive proposal put forward is that of Bagemihl (1988b), who presents a detailed model of the ludling component based on data from more than fifty ludlings (schematised below). This model (also couched within the lexical phonology framework) preserves Mohanan's (1986) (and others) essential insight about an intermediate location of the ludling component, but posits a highly modularized internal structure to account for the cross-ludling variations. The basis of this model is a highly articulated conception of the post-lexical phonology-syntax interface, combining proposals of Selkirk (1990), Pulleyblank (1986), Mohanan (1986), and others, which converge in the recognition of at least five post-lexical levels of representations within the nonludling phonology.

Each Kirundi game has a different input. The / ${ }^{\prime \mu} \mathrm{sV} /$ and /'mnV/ word games take the output of the voice dissimilation in ordinary Kirundi as an input, whereas the /'ka/ game takes for input the data where dissimilation has not yet applied, as illustrated in (42). 
(42)

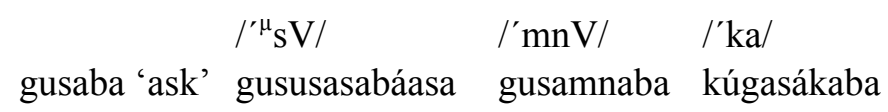

The realization of the voice dissimilation rule definitely constitutes a challenge for Lexical phonology since, as a morphological rule, it applies both at the lexical level, to the output of morphological rules, and at the postlexical level, to the output of phonological rules as exemplified in (43). In this sense, the boundary between the prefixal component and the stem is permeable. The rule still 'sees' the morphological boundary even after phonological rules have applied. Let us look at the following example (43).

\section{(43) Phrase Gloss Phonological Word /'ka/ game mu ishaamba 'in forest' mw'iishaamba mwigashákamba}

The example in (43) shows that the infix, /'ka/, is inserted after glide formation between the locative $/ \mathrm{mu} /$ and the preprefix $/ \mathrm{i} /$. This infix applies to the output of glide formation, otherwise the result would be *mukaikashakamba (perhaps followed by some vowel fusion or deletion to avoid vowel hiatus). 
78 Phonological Readjustment Kirundi Language Games

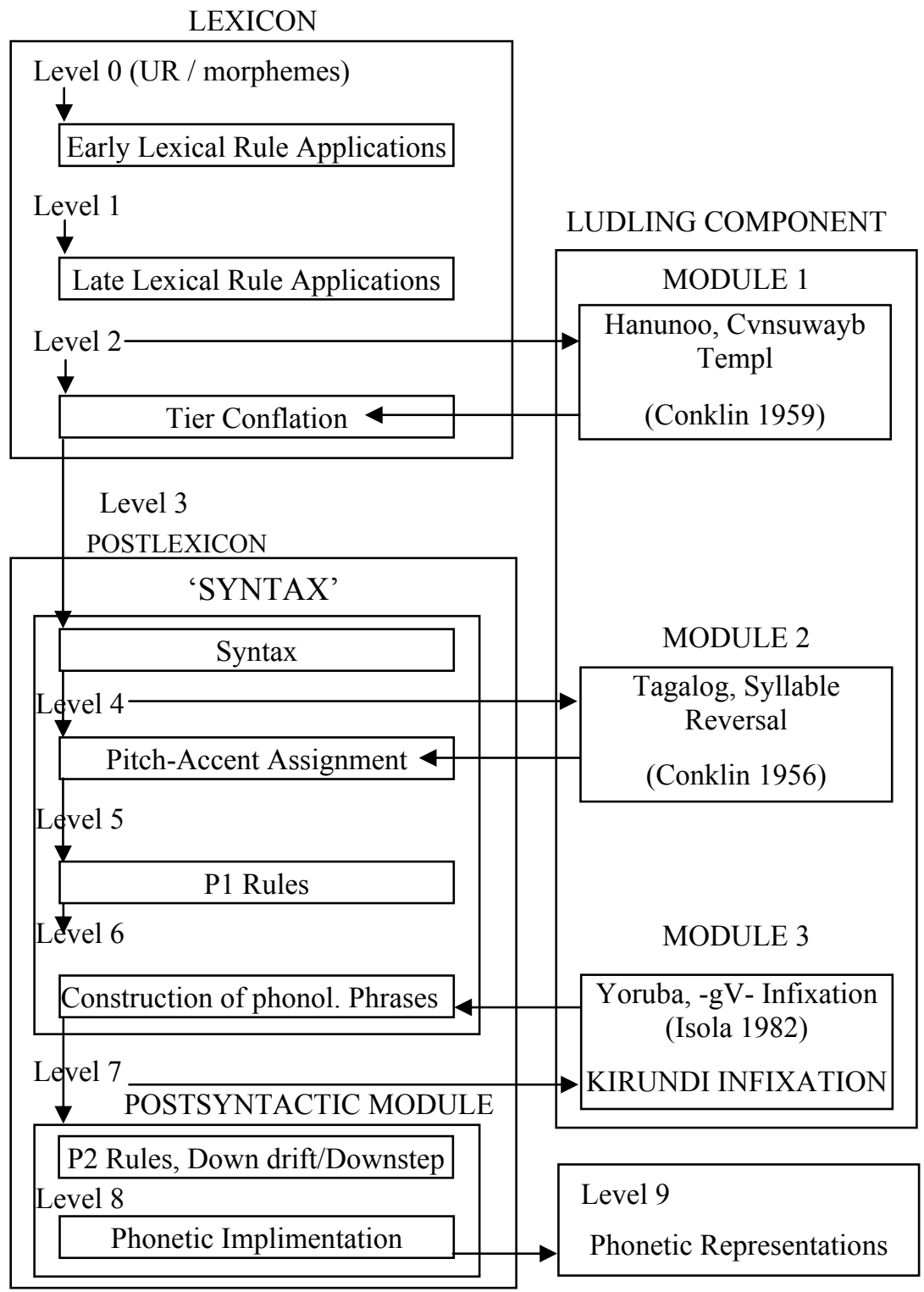

Chart 1. Bagemihl's Modular Model (1995) 
Bagemihl (1995: 708-709) claims that according to his model, there are three points in the grammar where the ludling component can access the phonological representation, each corresponding to a particularly salient juncture within the grammar. The first module is located at the output of the lexicon prior to Tier Conflation. The assumption is that Tier (or Plane) Conflation applies only once, at the end of the lexicon, as proposed by Cole (1987). The second module is located at the output of the syntax prior to the post-lexical phonology. The third module is at the division between the syntactic and postsyntactic modules of the postlexicon. Depending on which module a ludling is assigned to, it will exhibit a variety of distinctive properties which are specific to that location, summarized below.

(44) Ludling Properties

a. Follow all lexical phonological / morphological processes

b. Precede $\mathrm{P} 2$ postlexical rules and Phonetic implementation

c. Follow Tier/Place Conflation

d. May violate Melodic Conservation

e. May apply between words/access sentence position

f. Precede intonation/pitch-accent assignment

g. Precede P1 post-lexical rules

h. May access post-lexical prosodic constituents

i. May violate geminate integrity, OCP

j. May ignore function words

k. Are structure-violating. (Bagemihl 1995: 710)

The use of several modules within the ludling component has many advantages. In addition to accounting for the cluster of properties associated with each conversion location. Two of them are of particular interest for the purpose of this thesis. First, they predict that a given language can have ludlings located in different modules. Bagemihl (1995: 710) gives the example of Tagalog Segment Reversal, a Module 1 ludling, whereas Syllable Reversal in 
the same language is a Module 3 ludling. The Kirundi affixation games also appear in different modules, as we see below. Second, the operations associated with a single ludling may be distributed across more than one module.

Bagemihl illustrates the case with one Hanunoo ludling that involves reduplication of non-ludling syllables (a Module 1 operation) and insertion of clitics between words and at phrase boundaries (a Module 3 operation). In Kirundi Incanganyo, as we see below, voice dissimilation rule applies in a Module different from that of vowel shortening.

\subsection{The Case of Voice Dissimilation in Kirundi Language Games}

As the data in Table 1 above show, $/ \mathrm{k} /$ of the infix /'ka/ undergoes voicing when it is followed by a stem initial voiceless consonant. As is apparent from the above survey of Kirundi games, 'source language' means different things in different contexts. An adequate treatment of language games should capture the empirical typology within the confines of a parameterized theory. I will now demonstrate that the three types of language games instantiate three possible levels of "source language" that are independently established in phonology. As Goldsmith and Sabimana (1989: 55) point out, Kirundi morphology can be made clearer with a diagram, a layered model of morphology reminiscent of lexical phonology. According to them, "Level 1 creates the derivational base, consisting of the radical and the derivational extensions. Subsequently, the Final Vowel, the Object Marker prefixes, the Tense or Focus markers, the negative marker, and the subject markers are added. Each of the two layers has distinct phonological rules. Layer 2, for example, contains the dissimilation rule, which is triggered in Kirundi only by a radical-initial voiceless consonant (not, for example, an Object Marker beginning with a voiceless consonant)"; the rule is presented in (45). 
(45) Voice dissimilation rule

$[\mathrm{c}]_{- \text {voice }} \rightarrow[+$ voice $] /-\mathrm{V}+[\mathrm{c}]_{\text {- voice }}$

In other words, voice dissimilation in Kirundi voices an obstruent in a morpheme that immediately precedes a stem beginning with a voiceless obstruent.

Goldsmith and Sabimana argue that "the operation of this rule shows that voice dissimilation rule cannot apply cyclically with the addition of each prefix, since it is blocked from applying to the subordinate negative $-t a$ - just in case a nasal Subject Marker prefix precedes it". Let us look at the following examples:

(46) a lexical rule:
a. ku-kóra
$\rightarrow$ gukóra
'to work'
b. i-ki-íibuk-y-o $\rightarrow$ icíibutso 'souvenir'
c. I-ki-íicar-o $\rightarrow$ icíicaro 'a seat'
d. a-ka-íicar-o $\rightarrow$ akíicaro 'a small seat'

(47) a postlexical rule (also see Goldsmith 1992: 153)
a. u-ta-tema
$\rightarrow$ udatema 'that you not cut'
b. n-ta-tema
$\rightarrow$ [nhatema] 'that I not cut'

The breathy aspiration is allophonic and therefore postlexical rule
c. nka inda
$\rightarrow$ nkínda
'like a stomach'
d. nka indá
$\rightarrow$ nkín'indá 'like a flea'

(48) BUT:
a. a-ka-tema
$\rightarrow$ agatema 'that $\mathrm{s} /$ he cut'
b. a-ka-íí-tema
$\rightarrow$ akíitema 'that s/he cut self'

The stem boundary is still felt in the examples (46d) and (48b), whereas it's not felt in the examples of the /'ka/ game as in 
82 Phonological Readjustment Kirundi Language Games

\section{kúgakikana.}

Goldsmith and Sabimana (1989: 56) assume that a stem is endowed with inflectional features and that it can be viewed as passing through the rules of inflectional morphology, realizing each of the specified inflectional features. The stem may be assigned the category Noun or Verb; if it is assigned the category noun, it will undergo noun class prefixation (class 15) to become an infinitive. The fact that Dahl's Law affects noun class prefixes is one clue that noun class prefixes are indeed added in Layer 2. Many of the other prefixation processes (prefixation of Subject Marker, for example) are restricted to verbs. In the third layer, a high-level word can be created by the attachment of outer layer of prefixes, including nti-, a negative marker, and zóo-, a future tense marker. The fact that the dissimilation rule does not apply at the phrase boundary or between a Subject Marker and an Object Marker constitutes evidence for the strictly morphological application of this rule. More examples are presented in Table 2 to illustrate the multilevel application of Dahl's Law.

Table 2. More examples of /'ka/ game

\begin{tabular}{|l|l|l|l|}
\hline \multicolumn{1}{|c|}{ Underlying } & \multicolumn{1}{|c|}{$\begin{array}{c}\text { Regular } \\
\text { Kirundi }\end{array}$} & \multicolumn{1}{c|}{-ka game } & \multicolumn{1}{c|}{ Gloss } \\
\hline (1) ku-ta & guta & kúgata & to throw away \\
\hline (2) ku-í́kaanda & kwí́kaanda & kwíkakákanda & to massage \\
\hline (3) ku-aka & kwaaka & kwákaka & to burn (fire) \\
\hline (4) ku-ak-ya & kwaatsa & kwákatsa & to turn on \\
\hline (5) ku-ugara & kwuugara & kwúkagákara & to close \\
\hline (6) ku-iítaba & kwí́taba & kwíkatákaba & to answer a call \\
\hline (7) ku isoko & kwíisoko & kwíkasókako & at the market \\
\hline (8) a-ka-ícaro & akiícaro & ákakíkacíkaro & a small seat \\
\hline (9) a-ka-áto & akaáto & ákakákato & a small calabash \\
\hline (10) a-ka-oto & akooto & ákakókato & little fire \\
\hline
\end{tabular}




\begin{tabular}{|l|l|l|l|}
\hline (11) a-ka-tema & agatema & ákakágatékama & s/he would cut \\
\hline (12) a-ka-íi-tema & Akiítema & Ákakíkatékama & $\begin{array}{l}\text { s/he would cut } \\
\text { himself }\end{array}$ \\
\hline
\end{tabular}

In example (1) of Table 2, the dissimilation rule applies properly because its structural description is met. However, it does not apply in the rest of the examples (2-12) because in the regular Kirundi column of these examples the stem initial sound is a vowel, which is voiced. In the /'ka/ game column, the voice dissimilation rule does not apply because the voiceless consonant that is supposed to trigger the dissimilation is not stem initial. In other words, the structural description of the voice dissimilation rule is not met in this set of examples.

So far two rules show the necessity of a multilevel model of representation in Kirundi language games. These are: the vowel shortening after compensatory lengthening and the voice dissimilation rule. The model proposed by Goldsmith and Sabimana (1989: 57) fits the purpose of this analysis. 
84 Phonological Readjustment Kirundi Language Games

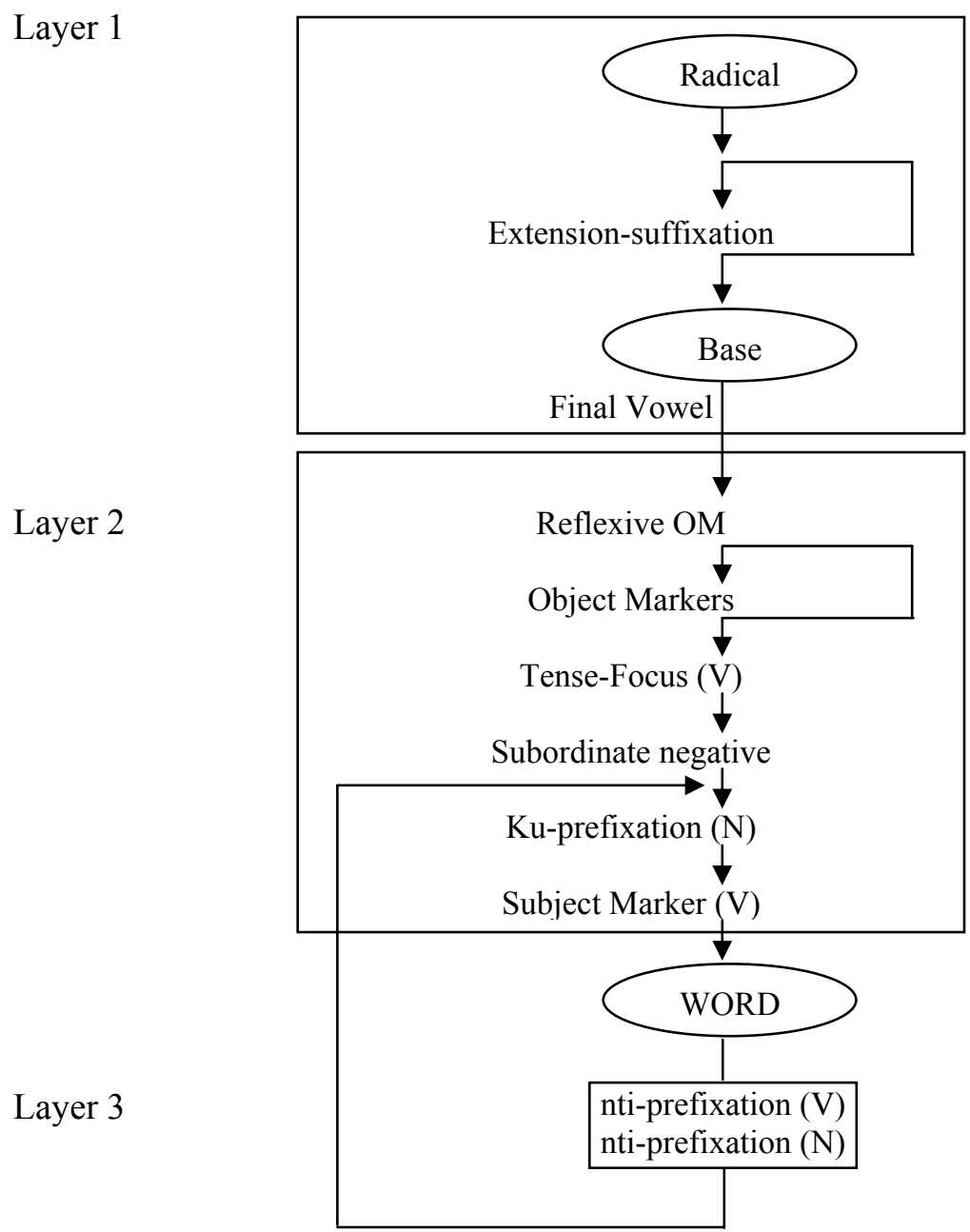

Chart 2. The Kirundi Verb (Goldsmith \& Sabimana 1989: 57) 
According to Sherzer (1970: 351), the Cuna word game Sorsik summakke "provides evidence for the view that ... several models (i.e. grammars) are in use in a speech community". Sherzer discusses several "phonological problems" (cases for which an analyst might have difficulty in deciding among possible analyses), and argues that in some cases the sorsik sunmakke data "indicate that all speakers agree with respect to their solutions", while in others these data "suggest that speakers have alternative solutions" (Sherzer 1970: 344).

The phonological problem at hand in Kirundi is: does voice dissimilation only apply at the lexical level since it is a word-level morphological rule? Examples such as those in (50) indicate that $/$ 'ka/ game applies at the postlexical level after vowel deletion has applied.
a. nka inda $\rightarrow$ nkínda nkíkanda 'like a stomack'
b. nka indá $\rightarrow$ nkíninda nkíkanda 'like a flea'
c. ko umugabo umwe $\rightarrow$ k'umugab'umwe $\rightarrow$ kúkamúkágákabúkamwe 'of (CL12) one man'

In examples (50), the /'ka/ game applies after connective vowel deletion. These data indicate that some level other than the underlying representation must, at least in some cases, be the input to the rules of the game. As Sherzer (1976: 30) points out, the rule involved in Verlan 2 "must operate after the ordinary French rules of elision." Thus l' école /la ekol/ is treated as a 'phonological word' for the purposes of the game, and in its output (in French orthography) is qu'élole (cf. Sherzer 1976: 25). 


\section{Conclusion}

The data discussed in this paper all involve prosodic suffixation, as a linguistic mechanism used to produce language game forms. The common pattern is that the game suffixes impose their own prosodic structure (tone and quantity). In this paper, the data demonstrate three things.

First, the data show that vowel length and tone contrasting neutralization is not uncommon in the native speaker linguistic system. They illustrate an overall length and tone contrast neutralization. All three types of language games, $/{ }^{\prime} \mathrm{ka} /, /{ }^{\prime \mu} \mathrm{sV} /$, and /'mnV/, show that the only length and tone that surfaces is the one that comes with the infixed material. The underlying tone or vowel length and the derived ones are completely neutralized in all environments. This fact thus complicates the decision about the possible input to the language games.

Second, I demonstrated that the source language of the language games belongs to different modules depending on the nature of the ludling. This paper presents structural similarities between language games and the issue of the possible input to the language games, considering that tone and vowel length do not constitute evidence for the Source language. In addition, I show that one ludling can pertain to different modules depending on its characteristics. Kirundi affixation games fit well in Bagemihl's model (1995). Even the voice dissimilation process that applies at different levels is accounted for. The operations associated with a single language game may be distributed across more than one module. However, this formulation does not accommodate the fact that the dissimilation rule is a typical lexical rule sensitive to word-level morphological considerations. Whereas voice dissimilation suggests that the source language for the Kirundi language game, /'ka/ affixation is the underlying form of Kirundi, and the output of other phonological processes, such as palatalization and vowel deletion, 
constitutes input to the language games. As the data show, this apparent contradiction presents a problem for Lexical phonology.

Third, I showed that prosodic theory, as proposed in McCarthy and Prince $(1986,1990)$ best accounts for the Kirundi language game affixation. Kirundi language game data provide supporting evidence that melodic tier and prosodic tier are two levels of representation. Tone is assigned by storing metrical constituents, building feet using Idsardi's (1992) Simplified Bracketed Grids (SBG), and inserting tones at edges of feet. Like vowel length, tonal contrast is neutralized across the board at the expense of the tone attached to the infixed segmental material. Prosody characterizes the shape of both the input and the output of language games. The data analyzed in this study provide additional evidence for the valuable insights into the phonology of human languages from the phonological units such as the syllable to the phonological rules such voice dissimilation.

\section{References}

Alidou, O. 1997. A Phonological Study of Language Games in Six Languages of Niger. Ph.D. Dissertation. Bloomington, IN: Indiana University.

Bagemihl, B. 1988a. Alternate Phonologies and Morphologies. Ph.D. Dissertation. British Columbia: University of British Columbia.

. 1988b. The Morphology and Phonology of Katajjait (Inuit Throat Games). CJL 33, 1-58.

. 1995. Language Games and Related Areas. In J. Goldsmith (ed.), The Handbook of Phonological Theory 697-712. Cambridge: Blackwell.

Churma, D. 1985. Arguments from External Evidence in Phonology. New York: Garland Press.

Clements, G. 1981. An Outline of Luganda Syllable Structure. SAL Supplement 8, 12-16. 
88 Phonological Readjustment Kirundi Language Games

Clements, G \& J. Goldsmith. 1984. Autosegmental Studies in Bantu Tone. Dordrecht: Foris.

Cole, J. 1987. Planar Phonology and Morphology. Ph.D. Dissertation. Cambridge, MA: Massachusetts Institute of Technology.

Cowan, N. \& A. Lewis. 1990. Speakers' Access to the Phonological

Structure of the Syllable in Word Games. CLS 26. 2, 44-59.

Goldsmith, J. 1992. Note on the Genealogy of Research Traditions in Modern Phonology. Linguistics 28, 149-163.

Goldsmith, J. \& G. Clements. 1984. Autosegmental Studies in Bantu Tone:

Introduction. In G. Clements \& J. Goldsmith (eds.), Autosegmental

Studies in Bantu Tone 1-17. Dordrecht: Foris.

Goldsmith, J. \& S. Firmard. 1989. The Kirundi Verb. In F. Jouannet (ed.), Modèles en tonologie. Paris: Centre National de la Recherche Scientifique.

Hayes, B. 1995. Metrical Stress Theory: Principles and Case Studies. Chicago, IL: Chicago University Press.

Hombert, J. 1986. Word Games: Some Implications for Analysis of Tone and Other Phonological Constructs. In J. Ohala, \& J. Jaeger (eds.), Experimental Phonology 175-186. New York: Academic Press.

Idsardi, W. 1992. The Computation of Prosody. Ph.D. Dissertation. Cambridge, MA: Massachusetts Institute of Technology.

Laycock, D. 1969. Sublanguages in Buin: Play, Poetry, and Preservation.

Pacific Linguistics A 22, 1-23.

. 1972. Towards a Typology of Play-languages, or Ludlings. Linguistic

Communications 6, 61-113.

Lehiste, I. 1985. An Estonian Word Game and the Phonematic Status of Long Vowels. Linguistic Inquiry 16, 490-492.

McCarthy, J. \& S. Alan. 1986. Prosodic Morphology. MS, Cambridge, MA: University of Massachusetts \& Brandeis University. . 1990. Foot and Word in Prosodic Morphology: The Arabic Broken Plurals. Natural Language and Linguistic Theory 8, 209-282.

Mohanan, K. 1986. The Theory of Lexical Phonology. Dordrecht: Reidel. Pulleyblank, D. 1986. Tone in Lexical Phonology. Dordrecht: Reidel. 
Selkirk, E. 1990. A Two-root Theory of Length. University of Massachusetts Occasional Papers 14, 123-171.

Sherzer, J. 1976. Play Languages: Implications for Sociolinguistics. In B. Kirshenblatt-Gimblett (ed.), Speech Play: Research and Resources for the Study of Linguistic Creativity 19-36. Philadelphia, PA: University of Pennsylvania Press. . 1982. Play Languages: With a Note on Ritual Languages. In L. Obler \& M. Lise (eds.), Exceptional Language and Linguistics 175-199. New York: Academic Press.

Yip, M. 1994. Isolated Uses of Prosodic Categories. In J. Cole \& C. Kisseberth (eds.), Perspectives in Phonology 293-311. Stanford, CA: CSLI Publications. 